\title{
Political Responsibility of the Deputy of the Regional Parliament in the Russian Federation
}

\author{
Ruslan F. Garipov ${ }^{1}$ \\ ${ }^{1}$ Kazan Federal University, Institute of Sociology, Philosophy and Mass Communications, Russia \\ Correspondence: Ruslan F. Garipov, Kazan Federal University, Institute of Sociology, Philosophy and Mass \\ Communications, Russia. E-mail: ruslanweb@bk.ru
}

Received: June 9, 2019

Accepted: August 25, $2019 \quad$ Online Published: August 31, 2019

doi:10.5539/jpl.v12n5p92

URL: https://doi.org/10.5539/jpl.v12n5p92

\begin{abstract}
This work studies the distinctive features of political responsibility of regional deputies representing the interests of various electoral groups. The status of a regional parliament deputy in Russian regions is characterized in two ways. It is regulated not only by laws and ethical norms, but also by political guidelines. Regional deputies are held legally accountable for violating laws, and by straying from party or state guidelines, they risk being held politically accountable. This is why the object of study of this article is the negative consequences that regional deputies suffer as a result of the political practices in Russian regions. In 2016-2019, there was an expansion of legal grounds that affect termination of deputy duties. Deputies are frequently limited in their rights to address other participants of regional politics. In some cases, artificial barriers are created to interfere with the work of regional deputies. These limitations are political in nature, and thus have a vague definition in law. Because of that, the author pays special attention to the political norms that, if violated, result in special negative consequences for regional deputies, including their inability to perform their parliamentary duties.
\end{abstract}

Keywords: political responsibility, regional deputy, regional partliament, deputy's responsibility, Russian regions, political conflict

\section{Introduction}

All Russian regions have their own regional partliaments. The operation of these legislative bodies is based on general democractic principles: laws and other resolutions are considered passed if a simple majority of deputies votes to support them. Regional parliaments are formed by holding elections among voters living in the specific Russian region. However, being elected to the parliament does not guarantee that the deputy will maintain their special political and legal status during their entire term at the local legislative body.

Deputies can be stripped of their mandate for two reasons:

- objective inability to participate in parliamentary activities (due to health, loss of citizenship, or legal incapacity); - subjective reasons, when the deputy is found guilty of a certain violation of law.

In most cases, deputies of regional parliaments are subject to legal liability. Such liability is specified in regional constitutions and codes passed in the Russian regions, as well as in special-purpose laws that determine a special procedure for prosecuting the liable deputy. For that reason, regional parliament members possess partial immunity. Federal Law No. 184-FZ of 1999 mandates the use of a special procedure if a regional deputy becomes subject to administrative or criminal liability. Furthermore, deputies are granted immunity that frees them from liability for statements and opinions. However, such immunity does not cover libel and public insults committed by a deputy.

In some cases, the liability of regional deputies is solely political. For that reason, such liability is applied for violating not only legal norms, but also political norms.

These specifics of the liability of deputies affected the direction of development of the political science. For a long time, the formal law method dominated in understanding political responsibility. Today, a deputy's responsibility has a larger meaning. It manifests in any negative measures applied against the guilty parliament member. If a deputy violates political norms, the liablity imposed on them is of a governance-related nature. For that reason, modern science differentiates political responsibility from other liability that regional deputies may be subject to. 


\section{Methods}

The methodological basis consists in systematic and functional study of political responsibility. As a consequence, there are three main approaches to understanding it.

According to the first approach, political responsibility is a constitutionally defined set of negative measures against the governing subjects. Therefore the constitutional and legal liability of deputies is deemed identical to their political responsibility. Thus, the use of sanctions stated in constitutional law against these persons is recognized as cases of political responsibility.

The second approach reduces the political responsibility to merely administrative, legal and disciplinary measures. They are applied against deputies on the official state level. With this definition, if a deputy is stripped of their powers or these powers are significantly restricted, they experience the negative consequence of their 'wrong' behavior in the process of exercising their governance. Thus, for example, if a deputy is stripped of the right to speak during a parliamentary session, researchers treat it as political responsibility.

The third approach defines political responsibility as a complex institution, where a deputy is influenced by various negative measures to correct their future behavior. In that respect, a deputy may be subject to legal liability, including some disciplinary sanctions, as well as financial measures and nonlegal tools of influence (for instance, ignoring their communication, refusal to provide information, etc.).

The validity of the results of this study is based on the concept dominating in the literature that if an official is held liable, their political activity is being influenced. These manipulations prevent the development of a deputy's career. Therefore the limitation and stripping of powers of deputies are considered as part of political responsibility. This is evidenced by examples of political practices cited by the author in this article.

\section{Results and Discussion}

If a deputy is held politically responsible, the measures that can be taken against them are restricted by law. However, deputies in Russian regional parliaments are subject to a wider range of negative consequences when they are being held politically liable. In special literature, any action by a subject of power against a guilty person is called a "liability" or "responsibility". If such action is taken against a deputy who has violated certain norms and guidelines, this constitutes "political sanctions".

Russian regional law currently provides only two negative measures:

- disallowing the deputy to speak at a parliamentary session;

- early termination of the deputy's duties.

These measures are regulated by law, and therefore they are treated as cases of special legal liability for regional deputies. However, not all conditions for applying such sanctions are regulated by law.

For instance, Article 56 of the Rules of the State Council of the Republic of Tatarstan (the State Council is the parliament of the Republic of Tatarstan, which is a part of the Russian Federation) permits restricting a deputy from speaking. They can be restricted from speaking at one or more parliamentary sessions. The Rules of the State Council of the Republic of Tatarstan do not specify any limits on the use of such sanction. This issue is left to the discretion of the person presiding at the parliamentary session. In the Republic of Tatarstan, this person is the Chairman of the State Council. This function can also be performed by others. Thus, in accordance with Article 64 of the Rules of the State Council, such other persons include: Deputy Chairman, and chairmen of committees of the State Council of the Republic of Tatarstan.

Persons who replace the absent Chairman of the State Council of the Republic of Tatarstan can also preside at hearings in the regional parliament. Current regulations do not define the range of persons authorized to do so. If we follow the political practices in the Republic of Tatarstan, such power is granted to the President of Tatarstan and the State Councillor of the Republic of Tatarstan (former President of Tatarstan).

From that, we can conclude that regional deputies may be held politically liable in Tatarstan by a more "powerful" official.

This issue is also not settled in the parliaments of other Russian regions. For instance, under Paragraph 5, Article 15 of the Rules of the Legislative Assembly of the Krasnoyarsk Krai, any person can "preside" if they substitute for the absent Chairman of the parliament. For that reason, other officials are forbidden from restricting the right of deputies to speak in the parliament.

However, these Rules contain a wider provision permitting the use of this sanction. In the State Council of the Republic of Tatarstan, the guilty deputy first receives a "warning", and only then is stripped of the right to speak. In 
the Legislative Assembly of Krasnoyarsk Krai, a deputy may be stripped of that right without a prior warning. This penalty is used for "rude" and "offensive" phrases, and in cases when a deputy's speech causes "offense to the honor and dignity of citizens and officials". Deputies can also be stripped of that right for unfounded accusations against other persons. These grounds for political responsibility significantly reduce the freedom of speech in the parliament. This affects the right of deputies to freely speak and criticize decisions of the regional government and ministries.

Besides the legal options for punishing a deputy, Russian regions practice other, nonlegal measures of influence. They are not set in law, but are still used in regional political practice. This particularly includes limiting specific rights of deputies to contact other government bodies. If a deputy is in sharp opposition and actively criticizes officials and the government, artificial barriers can be imposed on him in his work.

For instance, in 2014-2019, a political conflict has been developing between the Legislative Assembly and the Government of the federal city of Sevastopol (such cities are treated as a separate region of the Russian Federation). In 2017, the Governor of Sevastopol filed an administrative lawsuit against the Chairman of the Legislative Assembly, but the court rejected that lawsuit. In response, in 2018-2019, the Government of Sevastopol stopped responding to queries from the municipal deputies. Deputies were also refused access to meetings of regional ministries. These sanctions are not envisioned in the law of Sevastopol, but are actively used in the developing conflict between the two branches.

In 2016, a similar conflict occurred between the Government of the Nizhny Novgorod Region and the newly elected regional parliament, the Legislative Assembly of the Nizhny Novgorod Region. The issue arose because of the election of a new Chairman of the parliament. Some regional ministries started refusing deputies' requests for information. Opposition deputies were unable to schedule appointments with officials and participate in public hearings of other government bodies. Mikhail Babich, the Plenipotentiary Representative of the President of the Russian Federation in the Volga Federal District, intervened in this situation. Therefore a candidate supported by the governor was appointed the Chairman of the Parliament of the Nizhny Novgorod Region.

In some Russian regions, the conflict between the governor and the parliament is of an ideological nature. For instance, in 2012, the Governor of Vladimir Region was Nikolay Vinogradov, a member of the Communist Party of the Russian Federation. Most seats in the regional parliament belonged to the United Russia party. As a result, regional deputies overrode the governor's veto on the laws they passed. In 2018, the governor elections in Vladimir Region were won by Vladimir Sipyagin, a member of the Liberal Democratic Party. Because of that, the regional parliament passed a number of laws that require the governor to get his deputies and officials of the regional government approved by the parliament. Such conflict between the two branches of power in Vladimir Region did not occur during the term of Svetlana Orlova, the former governor and member of United Russia.

A similar political conflict is developing today in the Republic of Khakasiya. In 2018, Valentin Konovalov, a member of the Communist Party of the Russian Federation, became the governor. Most seats at the Republic's parliament belong to United Russia. The speaker of Khakasiya's parliament complained that the governor and some regional ministers refuse to discuss some bills in the parliament. The deputies were supported by Sergey Menyaylo, the Plenipotentiary Representative of the President of the Russian Federation in the Siberian Federal District. For that reason, the deputies won their conflict with the government of the Republic of Khakasiya. However, this does not prevent the government from applying political sanctions against them by limiting their right to contact ministries and the government.

\section{Summary}

The examples of political responsibility of regional deputies listed in this article evidence the use of a combination of legal and nonlegal measures. Sanctions against parliament members may manifest in broad interpretation of the conditions for limiting the rights of deputies. Nonlegal measures are not defined in laws, but they are applied against deputies by more influential regional politicians. Therefore the political responsibility of deputies in Russian regions bears an informal character. As a result, a stronger government official imposes their political will on the parliament. Political guidelines are thus being implemented. However, political responsibility of regional deputies in Russia may replace lawful methods of political conflict.

\section{Conclusions}

Political responsibility of regional deputies in the Russian Federation is applied in two cases. As a rule, it is of a partial nature and is only applied against specific deputies if they maintain rhetoric that is in radical opposition to the government and the governor. However, in recent years, there is an increasing number of cases when political sanctions are being applied to regional deputies to suppress a conflict between the legislative and executive 
branches. In some Russian regions, such political responsibility of deputies has an ideological basis resulting from the conflict between competing political parties.

\section{Acknowledgments}

The work is performed according to the Russian Government Program of Competitive Growth of Kazan Federal University.

\section{References}

Berlyavsky, L. G., \& Taraban, N. A. (2012). Recalling a deputy of a representative organ: political vs constitutional responsibility. Governance and Local Administration, (7), 30-33.

Brady, C. (1999). Collective responsibility of the Cabinet: an ethical, constitutional or managerial tool? Parliamentary Affairs, 52(2), 214. https://doi.org/10.1093/pa/52.2.214

Decree of the Legislative Assembly of Krasnoyarsk Krai No. 8-2963P dated 19 February 2009 (as amended on 5 July 2018) "Rules of the Legislative Assembly of Krasnoyarsk Krai", Herald of the Highest Level State Authorities of Krasnoyarsk Krai, No. 14 (310), 2009.

Decree of the State Council of the Republic of Tatarstan No. 2632 dated 26 February 2004 (as amended on 21 December 2017) "On the Rules of the State Council of the Republic of Tatarstan", Herald of the State Council of the Republic of Tatarstan, No. 12, p. 2285, 2017.

Doktorova, A. T. (2016). On the issue of responsibility of a people's deputy of the Republic of Sakha (Yakutiya) to voters. Governance and local administration, (3), 56-59.

Dunn, J. (1992). Interpreting political responsibility, Essays, 1981-1989. Canadian Journal of Political Science, 25, 192-193. https://doi.org/10.1017/S0008423900002237

Federal Law No. 184-FZ dated 6 October 1999 (as amended on 1 May 2019) "On general principles for organizing legislative (representative) and executive organs of state in regions of the Russian Federation". Official Gazette of the Russian Federation, № 18, p. 2218, 2019.

Gumiensky, J. (1996). Self-interest, national interest and the political leader's responsibility. UNLV Retrospective Theses \& Dissertations. Retrieved from https://digitalscholarship.unlv.edu/rtds/532

Israelyan, V. B. (2015). Political responsibility of deputies of legislative (representative) organs of state. Law and Society, 2(14), 225-231.

Knysh, V. V. (2017). Theoretic and legal aspects of interaction of constitutional and administrative responsibility. Sciences of Europe, 1(17), 65-69.

May, L. (1989). Philosophers and political responsibility. Social Research, 56, 877-901.

Peacock, M. S. (2004). On political competition: democracy, opinion and responsibility. Constitutional Political Economy, 15(2), 187-204. https://doi.org/10.1023/B:COPE.0000029643.66579.36

Shishkin, A. G. (2009). Legal liability measures, thesis for the Candidate of Legal Sciences, Ulyanovsk.

Trukhanov, V. A. (2016). Responsibility of subjects of the regional political process. Herald of the Saratov State Law Academy, 5(112), 219-221.

Tsakatika, M. (2004). Political responsibility and the European Union. Manchester University Press.

Tsutiyev, A. M., \& Tlyabichev, Sh. M. (2016). Parliamentary discipline and parliamentary responsibility of deputies. New Science: Contemporary State and Paths for Development, 12(4), 232-235.

\section{Copyrights}

Copyright for this article is retained by the author(s), with first publication rights granted to the journal.

This is an open-access article distributed under the terms and conditions of the Creative Commons Attribution license (http://creativecommons.org/licenses/by/4.0/). 